\title{
PENGARUH KUALITAS LAYANAN DAN KEWIRANIAGAAN TERHADAP KEPUASAN NASABAH KREDIT PENSIUN SERTA DAMPAKNYA PADA LOYALITAS NASABAH
}

\author{
Maman Sulaeman ${ }^{1}$, Sri Sudiarti², Sri Mulyati ${ }^{3}$, Dedeh Sundarsih ${ }^{4}$, \\ Devy Kustantini ${ }^{5}$ \\ 1,2,3,4 Dosen Politeknik Triguna Tasikmalaya \\ ${ }^{5}$ Karyawan Bank Saudara \\ *Korespondensi: mansulaeman1274@gmail.com
}

\begin{abstract}
Feedback from customers on the quality of services that have been given a reference in evaluating the ability of a Bank in creating customer satisfaction. The research method used in this study was survey method. The data collected by questionair and literature study. The population in this research were the pensions who have credit of pension at Bank Saudara 1906, Tbk branch Tasikmalaya. The determination of sample was based on the analyze variable amount and determined as many as 100 persons. The data analysis used path analysis. The research concluded that service quality and salesmanship was positive significant influented on consumer satisfaction. Simultaneously or partial of service quality and salesmanship was positive significant influent on Customer Loyalty. Customer Satisfaction was positive significant influent on Customer Loyalty. So the hypothesis is verified.
\end{abstract}

Keywords : Quality, Salesmanship, Customer Satisfaction, Customer Loyalty

\begin{abstract}
ABSTRAK
Umpan balik dari nasabah mengenai kualitas layanan jasa yang telah diberikan menjadi acuan dalam mengevaluasi kemampuan suatu Bank dalam menciptakan kepuasan nasabah. Metode penelitian yang digunakan adalah metode survey. Pengumpulan data diperoleh melalui kuesioner dan studi pustaka. Populasi dalam penelitian ini adalah nasabah yang menggunakan fasilitas kredit. Penentuan sampel berdasarkan jumlah variabel yang diteliti dan ditentukan sebanyak 100 orang. Analisis data yang digunakan adalah analisis jalur. Hasil penelitian menemukan bahwa baik secara parsial maupun secara simultan kualitas layanan dan kewiraniagaan berpengaruh terhadap kepuasan nasabah. Kualitas layanan dan kewiraniagaan berpengaruh terhadap loyalitas nasabah baik secara parsial ataupun simultan, dan kepuasan nasabah berpengaruh signifikan terhadap loyalitas nasabah.
\end{abstract}

Kata kunci : kualitas layanan, kewiraniagaan, kepuasan nasabah, loyalitas nasabah.

\section{PENDAHULUAN}

Pada situasi persaingan perbankan, bank-bank membutuhkan usaha yang keras untuk mendapat calon nasabah dan mempertahankan yang sudah ada ditangan. Keberhasilan usaha tersebut sangat ditentukan oleh kemampuan perusahaan dalam memberikan pelayanan yang berkualitas. Kualitas pelayanan tercermin dari kepuasan nasabah untuk melakukan penggunaan ulang jasa perbankan.

Kepuasan nasabah dalam menggunakan jasa atau produk yang ditawarkan dapat dijadikan masukan bagi pihak manajemen untuk meningkatkan dan memperbaiki kualitas pelayanan yang 
diberikan. Untuk itu karyawan bagian pelayanan sebaiknya selalu memantau kepuasan yang dirasakan oleh nasabah perbankan untuk mencapai loyalitas dari para nasabah.

Nasabah yang loyal adalah alat promosi yang efektif. Dengan adanya nasabah yang loyal akan sangat membantu pihak bank, karena nasabah yang loyal, merupakan alat promosi dari mulut ke mulut yang efektif. Nasabah yang loyal akan membawa nasabah lainya untuk menikmati pelayanan produk perusahaan. Semakin meningkat jumlah nasabah yang dilayani, semakin meningkat pula pendapatan dan laba perusahaan (Warta BRI, 2011).

Hubungan yang dinamis antara pemasar dengan konsumen dalam hal ini nasabah merupakan salah satu faktor yang dapat mempengaruhi kepuasan dan loyalitas. Salesmanship atau Kewiraniagaan yang merupakan bagian dari personal selling adalah salah satu strategi yang digunakan dalam bauran komunikasi pemasaran. Strategi ini memanfaatkan pendekatan personal kepada konsumen dimana inti dari kegiatan ini adalah menjalin hubungan yang dinamis dan fleksibel antar pihak yang terlibat dalam pemasaran. Dengan salesmanship nasabah akan lebih merasa diperhatikan dan memahami produk yang ditawarkan. Terdapat 3 (tiga) ciri khusus personal selling menurut (Tjiptono, 2008) yakni : 1) personal confrontation yaitu adanya hubungan yang hidup, langsung dan interaktif antara 2 orang atau lebih ;2) cultivation yaitu sifat yang memungkinkan berkembangnya segala macam hubungan, mulai dari sekedar hubungan jual beli sampai dengan suatu hubungan yang lebih akrab; 3) response yaitu situasi yang seolah-olah mengharuskan pelanggan untuk mendengar, memperhatikan, dan menanggapi.

Fenomena yang terjadi di Bank Saudara dalam pelayanan nasabah kredit pensiun terlihat bahwa untuk mendapatkan pelayanan dalam penyimpanan uang nasabah harus antri terlebih dahulu. Sebagaimana yang terlihat, nasabah yang antri tidak hanya bagi mereka yang menyetorkan uang (menabung), melakukan pembukaan rekening tetapi juga bagi mereka yang ingin melakukan print out atas buku tabungan, Pada awal bulan antrian nasabah hampir sampai tidak terlayani. Kondisi tersebut dapat berpengaruh terhadap kepuasan nasabah yang tentunya berdampak kepada loyalitas nasabah. Fenomena lainya pada Bank Saudara, setiap bulan selalu tercatat adanya pengajuan mutasi kantor bayar khususnya untuk para , baik untuk mutasi kantor bayar dari Bank Saudara ataupun mutasi kantor bayar ke Bank Saudara. Perpindahan penggunaan fasilitas kredit nasabah dari satu Bank Saudara ke Bank lain (Take Over) marak terjadi dan menjadi bentuk persaingan antar Bank. Rendahnya suku bunga kredit dibandingkan Bank pesaing menjadi salah satu alasan nasabah lebih tertarik untuk mengajukan pinjaman ke Bank Saudara. Contoh lainnya, ketika nasabah memilih untuk berpindah ke Bank Saudara dengan alasan sederhana karena ajakan orang lain, atau nasabah Bank Saudara yang tetap setia menjadi nasabah karena keramahan pelayanan yang diberikan oleh Bank Saudara. 
Setiap Bank memiliki strategi untuk menarik nasabah sebanyak mungkin dengan meningkatkan kualitas baik dari segi pelayanan ataupun produk yang tentunya didukung teknologi yang semakin berkembang. Bank Himpunan Saudara 1906, Tbk. merupakan salah satu bank swasta umum kelas menengah dengan aset sebagian besar dimiliki oleh pribumi dan memperluas jaringan bisnis di Tasikmalaya sejak tahun 2008. Segmentasi pasar Bank Saudara adalah para pegawai Negeri Sipil dan para pensiunan. Dalam kondisi persaingan yang ketat, Bank Saudara terus berupaya mengantisipasi perubahan yang terjadi dalam lingkungan bisnis jasa perbankan baik perubahan pada kebutuhan dan kepentingan nasabah dengan memperhatikan halhal yang menjadi kebutuhan, kepentingan, dan keinginan nasabah. Hal tersebut menjadi perhatian utama karena merupakan salah satu faktor yang sangat menentukan kepuasan nasabah, dan pada akhirnya akan meningkatkan loyalitas nasabah Bank Saudara.

Kemampuan Bank Saudara dalam memaknai arti penting kepuasan bertransaksi dan implikasi logis dari loyalitas nasabah merupakan salah satu cara untuk mengendalikan perilaku nasabah agar mereka tidak beralih ke lembaga keuangan pesaing. Bank Saudara terus memaksimalkan pelayanan kepada nasabahnya, diantaranya dengan meningkatkan jumlah kantor cabang, mengembangkan jaringan ATM, dan menambah fitur-fitur produk yang semakin beragam. Selanjutnya untuk lebih meningkatkan pelayanan jasa perbankan kepada masyarakat, Bank Saudara membuka kantor-kantor cabang di kota-kota wilayah priangan timur. Selain itu Bank Saudara juga didukung oleh ATM yang telah tergabung dengan jaringan ATM bersama. Divisi Funding and Services bank Saudara membentuk departemen Quality Service yang diharapkan dapat meningkatkan pelayanan kepada nasabah sehingga kepuasan nasabah dapat tercapai.

Salah satu produk unggulan dari Bank Saudara adalah Kredit Pensiun yaitu kredit yang diberikan kepada para pensiunan atau jandanya baik sipil, militer maupun swasta yang mempunyai Yayasan Dana Pensiun (YDP) dan menerima uang pensiun secara tetap setiap bulannya.

Fenomena yang terjadi di Bank Saudara dalam pelayanan nasabah kredit pensiun terlihat bahwa untuk mendapatkan pelayanan dalam penyimpanan uang nasabah harus antri terlebih dahulu. Sebagaimana yang terlihat, nasabah yang antri tidak hanya bagi mereka yang menyetorkan uang (menabung), melakukan pembukaan rekening tetapi juga bagi mereka yang ingin melakukan print out atas buku tabungan, Pada awal bulan antrian nasabah hampir sampai tidak terlayani. Kondisi tersebut dapat berpengaruh terhadap kepuasan nasabah yang tentunya berdampak kepada loyalitas nasabah. Fenomena lainya pada Bank Saudara, setiap bulan selalu tercatat adanya pengajuan mutasi kantor bayar khususnya untuk para pensiunan, baik untuk mutasi kantor bayar dari Bank Saudara ataupun mutasi kantor bayar ke Bank Saudara. 
Perpindahan penggunaan fasilitas kredit nasabah dari satu Bank Saudara ke Bank lain (Take Over) marak terjadi dan menjadi bentuk persaingan antar Bank. Rendahnya suku bunga kredit dibandingkan Bank pesaing menjadi salah satu alasan nasabah lebih tertarik untuk mengajukan pinjaman ke Bank Saudara. Contoh lainnya, ketika nasabah memilih untuk berpindah ke Bank Saudara dengan alasan sederhana karena ajakan orang lain, atau nasabah Bank Saudara yang tetap setia menjadi nasabah karena keramahan pelayanan yang diberikan oleh Bank Saudara.

\section{TINJAUAN PUSTAKA}

\subsection{Kualitas Layanan}

Layanan yang baik menjadi salah satu syarat kesuksesan dalam perusahaan jasa. Kualitas layanan dalam perusahaan jasa sering dikondisikan sebagai perbandingan antara layanan yang diharapkan dan layanan yang diterima secara nyata. Perusahaan yang mampu memberikan layanan yang baik kepada nasabah atau pelanggannya memiliki peluang terbesar untuk bisa terus dikunjungi oleh pelanggannya (Liu dan $\mathrm{Wu}, 2012$ ). Pada praktik dalam dunia perbankan saat ini, layanan nasabah dimasukkan sebagai salah satu syarat utama dalam upaya untuk memikat calon nasabah atau untuk melayani nasabah yang sudah ada (existing customers).

Dimensi mutu dari suatu jasa atau pelayanan tidak terlepas dari penilaian atas komponen jasa dari produk yang ditawarkan, dimana diantaranya yang terpenting adalah sistem penyampaian jasa tersebut (service delivery system). menurut (Tjiptono, 2008) terdapat 5 (lima) dimensi yang penting dari mutu jasa atau pelayanan yaitu: pertama adalah tampilan berwujud atau tangibles yang berbentuk fasilitas fisik, peralatan, personalia dan bahan-bahan komunikasi. Kedua adalah sesuatu hal yang dapat percaya atau reliability yaitu kemampuan untuk menyediakan jasa yang dijanjikan secara tepat dapat dipercaya. Ketiga adalah cepat tanggap atau responsiveness, yaitu keinginan untuk membantu pelanggan dan memberikan jasa yang cepat dan tepat. Keempat adalah jaminan atau assurance yang berupa pengetahuan dan keramahan karyawan serta kemampuan untuk memberitahukan secara meyakinkan dan dapat dipercaya. Kelima adalah rasa yang terdapat pada diri seseorang untuk tidak menggunakan emosinya, atau empathy, karena sangat kuat menekankan perhatiannya kepada orang lain yang dapat diberikan perusahaan kepada pelanggan.

\subsection{Salesmanship atau Kewiraniagaan}

Untuk mempengaruhi keputusan pembelian dari calon nasabah, maka diperlukan bauran promosi berupa periklanan, promosi penjualan, personal selling, pubilkasi dan direct selling. Diantara bauran promosi tersebut diketahui bahwa personal selling menjadi indikator yang paling mempengaruhi dalam keputusan pembelian di perusahaan penyedia jasa perbankan. Personal 
selling merupakan metode dan strategi yang tepat untuk mencapai tujuan perusahaan dalam menghadapi era globalisasi ini.

\subsection{Kepuasan Nasabah}

Kepuasan pelanggan merupakan suatu respon pelanggan terhadap ketidaksesuaian antara tingkat kepentingan sebelumnya dan kinerja aktual yang dirasakan setelah pemakaian. Menurut Kotler (2012), kepuasan pelanggan adalah tingkat perasaan seseorang setelah membandingkan kinerja yang dirasakan dengan harapannya. Untuk meningkatkan loyalitas, maka harus ditingkatkan kepuasan setiap pelanggan dan mempertahankan tingkat kepuasan tersebut dalam jangka panjang. Untuk meningkatkan kepuasan, perlu ditambahkan nilai pada apa yang ditawarkan. Menambahkan nilai akan membuat pelanggan merasa dirinya mendapat lebih dari apa yang mereka bayar atau bahkan lebih dari apa yang diharapkannya.

\subsection{Loyalitas Nasabah}

Loyalitas pelanggan akan menjadi kunci sukses, tidak hanya dalam jangka pendek, tetapi keunggulan bersaing yang berkelanjutan. Hal ini karena loyalitas pelanggan memiliki nilai strategis dan merupakan ikatan yang kuat bagi perusahaan. Berdasarkan pengertian yang ada, bahwa loyalitas pelanggan merupakan kesetiaan pelanggan terhadap perusahaan atau suatu produk tertentu dengan disertai tindakan untuk membeli kembali dan pelanggan konsumen bersedia mengembangkan hubungan kembali.

\subsection{Pengaruh Kualitas Layanan Terhadap Kepuasan}

Keterkaitan kualitas pelayanan dan kepuasan pelanggan dalam penelitian ini didasari pada pemikiran Hui, Kandampully dan Juwaheer (2009) beserta pemikiran Lai, Griffin dan Babin (2009) yang menyatakan bahwa Kualitas pelayanan berpengaruh positif terhadap kepuasan pelanggan. Kualitas pelayanan yang baik memiliki arti penting bagi kelangsungan hidup perusahaan karena dapat menciptakan kepuasan pelanggan.

Menurut Kotler (2012) Kepuasan pelanggan adalah Perasaan senang atau kecewa seseorang yang muncul setelah membandingkan antara persepsi atau kesannya terhadap kinerja atau hasil suatu produk dan harapan-harapannya. Bukti fisik yang baik akan mempengaruhi persepsi pelanggan. Pada saat yang bersamaan aspek ini juga merupakan salah satu sumber yang mempengaruhi harapan pelanggan. Karena dengan bukti fisik yang baik maka harapan konsumen menjadi lebih tinggi. Oleh karena itu merupakan hal yang penting bagi perusahaan untuk mengetahui seberapa jauh aspek wujud fisik yang paling tepat, yaitu masih memberikan impresi positif terhadap kualitas pelayanan yang diberikan tetapi tidak menyebabkan harapan pelanggan yang terlalu tinggi sehingga dapat memenuhi kebutuhan konsumen dan memberikan kepuasan kepada konsumen.

\subsection{Pengaruh Kewiraniagaan Terhadap Kepuasan}


Penerapan personal selling yang tepat dalam perusahaan akan memberikan kontribusi atau manfaat yang besar dalam memasarkan suatu produk. Dalam personal selling, tenaga penjual dapat secara langsung mengetahui kebutuhan, keinginan, motif, keluhan, dan perilaku konsumen sehingga dapat memberikan kepuasan kepada konsumen. Kusumadmo (2012) mengatakan bahwa dalam personal selling, para penjual dapat mengadakan penyesuaian akan pesan-pesan yang disampaikan kepada para pembeli menurut karakteristik yang unik dari setiap prospek atau calon pelanggan sehingga dapat memberikan kepuasan kepada konsumen.

\subsection{Pengaruh Kualitas Layanan dan Kewiraniagaan Terhadap Kepuasan}

Menurut Kotler dan Keller (2009) menciptakan hubungan yang kuat dan erat dengan pelanggan adalah mimpi semua pemasar dan hal ini sering menjadi kunci keberhasilan pemasaran jangka panjang. Untuk mendapatkan loyalitas pelanggan, institusi atau perusahaan perlu melakukan strategi pemasaran yang tepat agar dapat mempengaruhi loyalitas pelanggannya. Menurut Dharmmesta (2009), loyalitas terjadi apabila pelanggan merasa puas dengan merek atau kualitas pelayanan yang diterimanya, dan berniat untuk terus melanjutkan hubungannya dengan perusahaan tersebut. Dengan demikian loyalitas dapat terus dipertahankan apabila pihak penyedia jasa berusaha untuk memberikan kualitas pelayanan yang lebih baik kepada pelanggannya.

Menurut Mardalis (2012) bahwa salah satu faktor yang membuat pelanggan puas adalah kualitas jasa. Kualitas jasa ini mempunyai pengaruh terhadap kepuasan pelanggan. Pemasar dapat meningkatkan kualitas jasa untuk mengembangkan loyalitas pelanggan. Produk yang berkualitas rendah akan menanggung resiko pelanggan tidak setia. Jika kualitas diperhatikan, bahkan diperkuat dengan periklanan yang intensif, loyalitas pelanggan akan lebih mudah diperoleh.

\subsection{Pengaruh Kualitas Layanan Terhadap Loyalitas}

Hasil penelitian Akbar dan Parves (2009) menunjukkan terdapat hubungan yang positif dan signifikan antara kualitas pelayanan terhadap loyalitas pelanggan.Kumar et al. (2009) menyatakan bahwa kualitas pelayanan yang baik akan menghasilkan kepuasan pelanggan yang tinggi yang dapat meningkatkan loyalitaspelanggan. Dalam mengambil kebijakan untuk meningkatkan loyalitas nasabah, kualitas pelayanan perlu diperhatikan karena variabel ini berpengaruh positif dan signifikan terhadap loyalitas nasabah (Yani, 2012). Semua atribut kualitas pelayanan berpengaruh positif terhadap kepuasan pelanggan dan kepuasan pelanggan berkaitan langsung dengan loyalitas pelanggan (Siddiqi, 2011). Ehigie dalam Ladhari et al. (2011) juga menemukan bahwa kualitas pelayanan dan kepuasana dalah prediktor penting loyalitas nasabah bank.

\subsection{Pengaruh Kewiraniagaan Terhadap Loyalitas}

Salah satu unsur bauran komunikasi pemasaran adalah personal selling. personal selling merupakan metode dan strategi yang tepat untuk mecapai tujuan perusahaan dalam menghadapi 
era globalisasi ini. Personal selling adalah presentasi pribadi oleh para wiraniaga perusahaan dalam rangka mensukseskan penjualan dan membangun hubungan dengan pelanggan. Berdasarkan definisi tersebut, personal selling berbeda dengan kegiatan promosi lainnya. Dengan menggunakan personal selling konsumen akan lebih merasa diperhatikan dan lebih mudah untuk memahami prduk yang ditawarkan. Menurut Kotler dan Keller (2012) menyatakan bahwa : Personal Selling is an art. Effective sales people today have more than instinct, however. Companies now spend hundreds of million of dollars each year to train them in methods of analysis and customer management and to transform them from passive order takers into active order getters.

Menurut definisi Kotler (2012) dalam rangka mempertahankan pelanggan, banyak perusahaan memusatkan perhatian dengan meningkatkan tingkat kepuasan pelanggan. Tingkat kepuasan pelanggan merupakan suatu ukuran kunci. Tetapi, kepuasan pelanggan memimpin ke arah loyalitas pelanggan dan profitabilitas merupakan suatu persoalan penting yang penting untuk di uji. Promosi melalui personal selling merupakan cara yang paling banyak digunakan dalam dunia usaha saat ini. Sebagian orang berpendapat bahwa personal selling merupakan unsur yang dinamis dapat menggerakan sendi perekonomian. Dengan personal selling, konsumen dapat lebih jelas dan detail mengetahui kegunaan produk, apa keistimewaan produk, dan bagaimana cara penggunaan produk tersebut. Dengan semakin baiknya pelaksaanaan personal selling, maka sangat dimungkinkan loyalitas dari pelanggan semakin tinggi.

\subsection{Pengaruh Kualitas Layanan dan Kewiraniagaan Terhadap Loyalitas}

Konsumen yang puas terhadap barang dan jasa yang dikonsumsinya akan mempunyai kecendrungan untuk membeli ulang dari produsen yang sama. Kedua, kepuasan merupakan faktor yang akan mendorong adanya komunikasi dari mulut ke mulut yang bersifat positif (Suhartanto, 2012). Faktor dari efek kepuasan pelanggan terhadap perilaku adalah pelangan yang puas cendrung untuk mempertimbangkan penyedia jasa yang mampu memuaskan sebagai pertimbangan pertama jika ingin membeli barang atau jasa yang sama. Faktor terakhir ini dikenal sebagai faktor kognitif yang ditimbulkan oleh adanya kepuasan (Suhartanto, 2012).

Penelitian lainnya mengenai pengaruh kualitas layanan pada kepuasan dan loyalitas pelanggan grey consumers' juga menemukan bahwa kualitas layanan memiliki pengaruh yang positif dan signifikan terhadap kepuasan di department store dan juga loyalitas toko secara menyeluruh ( $L u$ dan Seock, 2008). Selain itu juga ditemukan bahwa kepuasan dapat menjadi intervening positif antara layanan ritel dan loyalitas pelanggan (Warniati, 2012). Penelitian yang dilakukan oleh Putra (2008), juga menunjukkan bahwa kualitas layanan yang diberikan oleh pihak Hypermart Bandung, ditemukan dapat menciptakan kepuasan pelanggan danmenimbulkan niat berperilaku pelanggan di masa yang akan datang. 


\subsection{Pengaruh Kepuasan dan Terhadap Loyalitas}

Loyalitas dapat tercipta jika perusahaan mampu memuaskan pelanggannya (Kotler, 2012). Jika kepuasan pelanggan terwujud maka loyalitas pada toko juga dapat terwujud (Omar dalam Semuel, 2006). Selain itu ditekankan bahwa loyalitas pelanggan pada toko adalah faktor penting dalam kesusksesan perdagangan eceran dan kemampuan toko untuk bertahan. Konsep kepuasan memiliki hubungan yang erat dengan loyalitas pelanggan dapat dilihat dari beberapa hasil studi seperti penelitian yang dilakukan oleh Chen dan Quester (2006) yang menghasilkan bahwa kepuasan memiliki efek yang positif terhadap loyalitas toko, di mana kepuasan itu dihasilkan dengan pelayanan karyawan yang baik, usaha untuk memberikan nilai lebih dan nilai ekonomis.

Kepuasan pelanggan menempati posisi penting dalam praktek di dunia bisnis karena manfaat yang dapat ditimbulkannya bagi perusahaan. Konsumen yang puas terhadap barang dan jasa yang dikonsumsinya akan mempunyai kecendrungan untuk membeli ulang dari produsen yang sama. Kedua, kepuasan merupakan faktor yang akan mendorong adanya komunikasi dari mulut ke mulut yang bersifat positif (Suhartanto, 2012).

\section{METODE}

Metode yang digunakan dalam penelitian ini adalah metode survey dimana untuk data yang diambil berupa sampel dengan cara sampling. Penelitian survey merupakan penelitian yang mengambil sampel dari suatu populasi dan menggunakan kuesioner sebagai alat pengambil data pokok. Adapun definisi dari metode Survey menurut Wibisono (2012) sebagai berikut: "Survey merupakan teknik riset dimana informasi dikumpulkan menggunakan penyebaran kuesioner. Populasi yang digunakan dalam penelitian ini adalah nasabah yang menggunakan fasilitas kredit untuk di Bank Saudara dengan rata-rata jumlah nasabah aktif sebanyak 3608 orang. Sampel yang diambil dalam penelitian ini tersebar di kantor cabang wilayah kerja priangan timur dengan kriteria sampel bersifat homogen, sehingga teknik sampling yang digunakan dalam penelitian ini adalah simple random sampling dengan rumus penentuan sampel sebagai berikut :

$$
\mathrm{n}=\frac{\mathrm{N}}{1+\mathrm{N}(\mathrm{d})^{2}}
$$

Keterangan :

$\mathrm{n}=$ Jumlah sampel minimal

$\mathrm{N}$ = Jumlah Populasi yaitu 3.608 Nasabah

$\mathrm{d}$ = Penyimpangan terhadap populasi $(0,1) 2$

Berdasarkan rumus diatas maka jumlah sampel yang diperoleh sebanyak : 


$$
\begin{aligned}
& \mathrm{n}=\frac{3608}{1+3608(0,1)^{2}} \\
& \mathrm{n}=97,2 \approx \text { dibulatkan menjadi } 100 \text { nasabah }
\end{aligned}
$$

Berdasarkan teknik sampling yang digunakan, maka besarnya jumlah sampel penelitian sebanyak 100 responden. Sampel diambil dengan membuat daftar elemen atau anggota populasi secara acak antara 1 sampai 3608, kemudian membagi dengan 100 maka intervalnya adalah 36, maka anggota populasi yang terkena sampel adalah setiap elemen yang mempunyai nomor nasabah kelipatan 36 yakni 1, 37, 73, 109 dan seterusnya sampai mencapai jumlah anggota 100 responden.

\begin{tabular}{|c|c|c|c|}
\hline Variabel & Dimensi & Indikator & Skala \\
\hline 1 & 2 & 3 & 4 \\
\hline \multirow{11}{*}{$\begin{array}{c}\text { Kualitas } \\
\text { Layanan }\left(\mathbf{X}_{1}\right) \text { : }\end{array}$} & \multirow{3}{*}{ Tangible } & Formulir tersedia lengkap & ordinal \\
\hline & & $\begin{array}{l}\text { Fasilitas hiburan untuk } \\
\text { menunggu antrian }\end{array}$ & ordinal \\
\hline & & Ruang tunggu nyaman & ordinal \\
\hline & \multirow{2}{*}{ Reliability } & $\begin{array}{l}\text { Kecepatan pelayanan dan } \\
\text { informasi }\end{array}$ & ordinal \\
\hline & & $\begin{array}{l}\text { Tidak terdapat kesalahan dalam } \\
\text { pelayanan }\end{array}$ & ordinal \\
\hline & \multirow{2}{*}{ Responsiveness } & $\begin{array}{l}\text { Respon petugas FL terhadap } \\
\text { saran dan kritik dr nasabah }\end{array}$ & ordinal \\
\hline & & $\begin{array}{l}\text { Penyelesaian komplain nasabah } \\
\text { secara cepat dan tepat }\end{array}$ & ordinal \\
\hline & \multirow{2}{*}{ Assurance } & $\begin{array}{l}\text { Pengetahuan dan kemampuan } \\
\text { para petugas }\end{array}$ & ordinal \\
\hline & & $\begin{array}{l}\text { Pemapuan petugas menerima } \\
\text { kepercayaan dan kerahasiaan }\end{array}$ & ordinal \\
\hline & \multirow{2}{*}{ Emphaty } & Kepedulian Petugas FL & ordinal \\
\hline & & Mendengarkan keluhan nasabah & ordinal \\
\hline \multirow{4}{*}{$\begin{array}{c}\text { Kewiraniagaan } \\
\qquad\left(\mathbf{X}_{2}\right):\end{array}$} & \multirow{2}{*}{$\begin{array}{l}\text { Mencari Calon } \\
\text { Pelanggan }\end{array}$} & $\begin{array}{l}\text { Kemampuan tenaga penjual } \\
\text { dalam menganalisa pasar }\end{array}$ & ordinal \\
\hline & & $\begin{array}{l}\text { Kemampuan dalam } \\
\text { mengkualifikasi pelanggan }\end{array}$ & ordinal \\
\hline & \multirow{2}{*}{ Pendekatan } & Ketepatan waktu & ordinal \\
\hline & & Kemampuan memulai & ordinal \\
\hline
\end{tabular}

Sesuai dengan judul penelitian yang diambil, maka penulis mengungkapkan beberapa variabel yang dioperasionalkan yaitu sebagai berikut:

Tabel 1. Operasionalisasi Variabel 


\begin{tabular}{|c|c|l|c|}
\hline & pembicaraan dengan menarik & \\
\cline { 2 - 4 } & $\begin{array}{c}\text { Presentasi dan } \\
\text { demontrasi }\end{array}$ & $\begin{array}{l}\text { Presentasi menimbulkan daya } \\
\text { minat beli }\end{array}$ & ordinal \\
\cline { 2 - 4 } Mengatasi & $\begin{array}{l}\text { Pengetahuan penjual tentang } \\
\text { produk }\end{array}$ & ordinal \\
\hline \multirow{2}{*}{$\begin{array}{l}\text { Keberatan } \\
\text { Pemampuan tenaga penjual } \\
\text { dalam menanyakan keluhan }\end{array}$} & $\begin{array}{l}\text { Kemampuan menjelaskan } \\
\text { jawaban penjual terhadap } \\
\text { keberatan nasabah }\end{array}$ & ordinal \\
\hline & $\begin{array}{l}\text { Kemampuan dalam menangkap } \\
\text { respon nasabah }\end{array}$ & ordinal \\
\cline { 2 - 4 } & $\begin{array}{l}\text { Kemampuan dalam } \\
\text { mempengaruhi nasabah untuk } \\
\text { mengambil kredit }\end{array}$ & ordinal \\
\hline
\end{tabular}




\begin{tabular}{|c|c|c|c|}
\hline 1 & 2 & 3 & 4 \\
\hline \multirow{6}{*}{$\begin{array}{c}\text { Kepuasan } \\
\text { Nasabah }\left(Y_{1}\right):\end{array}$} & $\begin{array}{c}\text { Pilihan yang } \\
\text { tepat }\end{array}$ & $\begin{array}{l}\text { Kepuasan nasabah terhadap } \\
\text { produk kredit yang diberikan }\end{array}$ & ordinal \\
\hline & \multirow[b]{2}{*}{$\begin{array}{l}\text { Kesesuaian } \\
\text { harapan }\end{array}$} & $\begin{array}{l}\text { Kepuasan nasabah terhadap } \\
\text { kecepatan pelayanan }\end{array}$ & \\
\hline & & $\begin{array}{l}\text { Kepuasan nasabah terhadap } \\
\text { kemampuan dan pengetahuan } \\
\text { karyawan bank }\end{array}$ & ordinal \\
\hline & \multirow{3}{*}{$\begin{array}{l}\text { Kepuasan } \\
\text { fasilitas }\end{array}$} & $\begin{array}{l}\text { Kepuasan nasabah terhadap } \\
\text { Sarana dan prasarana yang } \\
\text { memadai }\end{array}$ & ordinal \\
\hline & & $\begin{array}{l}\text { Kepuasan nasabah terhadap } \\
\text { Banking Hall yang nyaman }\end{array}$ & ordinal \\
\hline & & $\begin{array}{l}\text { Kepuasan nasabah dengan } \\
\text { Tersedianya lahan parkir }\end{array}$ & ordinal \\
\hline \multirow{7}{*}{$\begin{array}{c}\text { Loyalitas } \\
\text { Nasabah }\left(\mathbf{Y}_{2}\right) \text { : }\end{array}$} & \multirow{2}{*}{$\begin{array}{l}\text { Transaski } \\
\text { Ulang }\end{array}$} & $\begin{array}{l}\text { Melakukan rehab/ penambahan } \\
\text { plafond kredit }\end{array}$ & ordinal \\
\hline & & $\begin{array}{l}\text { Memanfaatkan fasilitas jasa } \\
\text { layanan lainnya di Bank Saudara }\end{array}$ & ordinal \\
\hline & \multirow[b]{2}{*}{$\begin{array}{c}\text { Referensi/ } \\
\text { Rekomendasi }\end{array}$} & $\begin{array}{l}\text { Mengajakn pensiunan lain untuk } \\
\text { mengambil kredit }\end{array}$ & ordinal \\
\hline & & $\begin{array}{l}\text { Mengajak nasabah lain untuk } \\
\text { menggunakan jasa layanan Bank } \\
\text { Saudara }\end{array}$ & ordinal \\
\hline & $\begin{array}{l}\text { Word } \\
\text { Of Mouth }\end{array}$ & $\begin{array}{l}\text { Memberikan informasi } \\
\text { mengenai kelebihan Bank } \\
\text { Saudara kepada orang lain }\end{array}$ & ordinal \\
\hline & \multirow{2}{*}{$\begin{array}{l}\text { Kesetiaan / } \\
\text { pilihan } \\
\text { pertama }\end{array}$} & $\begin{array}{l}\text { Tidak tertarik pada produk } \\
\text { pesaing }\end{array}$ & ordinal \\
\hline & & $\begin{array}{l}\text { Menjadikan Bank Saudara } \\
\text { sebagai pilihan pertama dalam } \\
\text { transaksi keuangan }\end{array}$ & ordinal \\
\hline
\end{tabular}

Data yang dihasilkan dari penyebaran kuesioner ini berskala ordinal mengingat kuesioner yang disebarkan menggunakan skala Likert dengan kisaran 1-5. Penggunaan skala ordinal tidak memungkinkan untuk memperoleh nilai mutlak (absolut) dari objek yang diteliti.

\subsection{Uji Validitas}

Uji Validitas digunakan untuk menguji ketetapan setiap item dalam mengukur instrumennya, teknik uji yang digunakan adalah teknik korelasi item total melalui Koefisien Korelasi Pearson. Reliabilitas menyangkut ketepatan alat ukur. Suatu alat ukur dikatakan mempunyai reliabilitas tinggi atau dapat dipercaya, jika alat ukur itu mantap, dalam pengertian bahwa alat ukur tersebut stabil, dapat diandalkan dan dapat diramalkan. Suatu alat ukur yang 
mantap tidak berubah-ubah pengukurannya dan dapat diandalkan karena penggunaan alat ukur tersebut berkali-kali akan memberikan hasil yang serupa. Suatu Pernyataan atau ukuran yang akurat adalah yang cocok dengan yang ingin diukur. Suatu alat ukur juga harus dapat mengantisipasi/mentolerir terjadinya error pengukuran yang random sifatnya. Hasil uji validitas dan reliabilitas menunjukkan semua pertanyaan valid dan reliabel dengan $r$ hitung dan nilai alpha $>$ dari 0,444 .

\subsection{Analisis Data}

Karena data yang diperoleh melalui kuesioner berskala pengukuran ordinal, maka skala ukuran tersebut harus diubah terlabih dahulu menjadi skala interval dengan menggunakan Method of Successive Interval (MSI). Mengacu kepada landasan teori dan kerangka pemikiran dalam gambar yang menghubungkan keterkaitan antara variabel. Maka analisis yang digunakan dalam penelitian ini adalah :

1) Koefisien Korelasi

2) Koefisien Determinasi

3) Pengujian Hipotesis

Adapun pengujian hipotesis penelitian yang akan penulis lakukan dengan prosedur sebagai berikut : Hipotesis nol adalah hipotesis yang menyatakan pengaruh $\mathrm{X}$ tidak signifikan terhadap Y, sedangkan hipotesis alternatif merupakan hipotesis penelitian dari peneliti yaitu prediksi yang diturunkan dari teori yang sedang diuji, dengan rumus yang digunakan adalah sebagai berikut :

$$
t=\frac{r \sqrt{n-2}}{\sqrt{1-r^{2}}}
$$

Dimana :

$$
\begin{array}{ll}
\mathrm{t} & =\text { nilai uji } \mathrm{t} \\
\mathrm{r} & =\text { nilai koefisien korelasi } \\
\mathrm{n}-2 & =\text { derajat kebebasan }
\end{array}
$$

\subsection{Path Analysis}

Mengacu kepada landasan teori dan kerangka pemikiran dalam gambar yang menghubungkan keterkaitan antara variabel X, dan Y. Maka analisis yang digunakan dalam penelitian ini adalah path analysis. Dengan analisis ini dapat dilihat besarnya koefisien jalur antara variabel bebas X1 dan X2 dengan variabel terikat Y1 dan Y2. Persamaan struktural yang menggambarkan hipotesis adalah:

$$
\begin{aligned}
& \mathrm{Y} 1=\mathrm{p}_{\mathrm{yx} 1} \mathrm{X} 1+\mathrm{p}_{\mathrm{yx} 2} \mathrm{X} 2+\mathrm{p}_{\mathrm{y}} \varepsilon_{1} \\
& \mathrm{Y} 2=\mathrm{p}_{\mathrm{Y} 2 \mathrm{x} 1} \mathrm{X} 1+\mathrm{p}_{\mathrm{Y} 2 \mathrm{x} 2} \mathrm{X} 2+\mathrm{Y} 2 \mathrm{y}_{\mathrm{y}} \mathrm{Y}+\mathrm{p}_{\mathrm{Y} 2} \varepsilon_{2}
\end{aligned}
$$

Berdasarkan data yang sudah tersusun, tahap selanjutnya menentukan jumlah skor untuk masing-masing variabel, karena skor merupakan data yang terbentuk ordinal, untuk keperluan 
perhitungan selanjutnya data tersebut perlu ditransformasikan kedalam bentuk data interval dengan menggunakan metode successive interval. Setelah itu, nilai-nilai skor untuk variabel dan tahap terakhir dilakukan penghitungan analisis jalur (path analysis). Pengaruh keterkaitan antar variable dapat dilihat sebagaimana gambar dibawah ini :

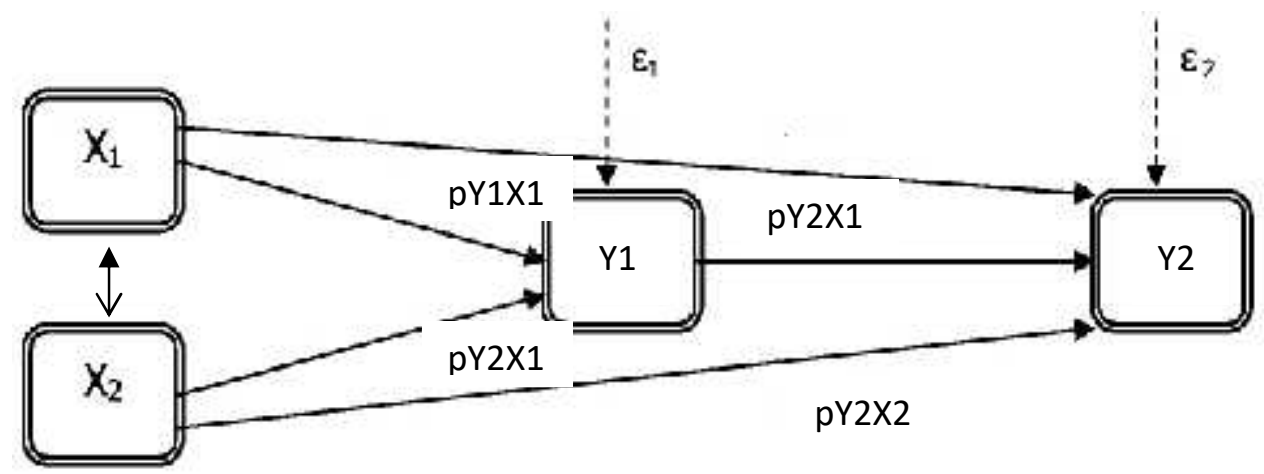

Gambar 3.1 Hubungan X1, X2, Y1 dan Y2

Dimana :

$\mathrm{X} 1=$ Kualitas Pelayanan

$\mathrm{X} 2=$ Kewiraniagaan

$\mathrm{Y} 1=$ Kepuasan Nasabah

$\mathrm{Y} 2=$ Loyalitas Nasabah

Pengujian hipotesis mediasi dapat dilakukan dengan prosedur yang dikembangkan oleh Sobel (1982) dan dikenal dengan uji Sobel (Sobel test). Uji sobel dilakukan dengan cara menguji kekuatan pengaruh tidak langsung variabel independen (X) ke variabel dependen (Y) melalui variabel intervening (M). Pengaruh tidak langsung $\mathrm{X}$ ke $\mathrm{Y}$ melalui $\mathrm{M}$ dihitung dengan cara mengalikan jalur $\mathrm{X} \rightarrow \mathrm{M}$ (a) dengan jalur $\mathrm{M} \rightarrow \mathrm{Y}(\mathrm{b})$ atau $\mathrm{ab}$. Jadi koefisien $\mathrm{ab}=\left(\mathrm{c}-\mathrm{c}^{\prime}\right)$, dimana $\mathrm{c}$ adalah pengaruh $\mathrm{X}$ terhadap $\mathrm{Y}$ tanpa mengontrol $\mathrm{M}$, sedangkan $\mathrm{c}^{\prime}$ adalah koefisien pengaruh $\mathrm{X}$ terhadap Y setelah mengontrol M. Standard error koefisien a dan b ditulis dengan $\mathrm{Sa}$ dan $\mathrm{Sb}$, besarnya standard error pengaruh tidak langsung (indirect effect) Sab dihitung dengan rumus dibawah ini :

$$
s_{b}=\sqrt{b^{2} s_{a}^{2}+a^{2} s_{b}^{2}}
$$

Untuk menguji signifikansi pengaruh tidak langsung, maka kita perlu menghitung nilai t dari koefisien ab dengan rumus sebagai berikut :

$$
t=\frac{a \dot{b}}{S a \dot{b}}
$$

Nilai t hitung ini dibandingkan dengan nilai $\mathrm{t}$ tabel yaitu $\geq 1,96$ untuk signifikan $5 \%$ dan $\mathrm{t}$ tabel $\geq 1,64$ menunjukkan nilai signifikansi $10 \%$. Jika nilai $t$ hitung lebih besar dari nilai $t$ tabel maka dapat disimpulkan terjadi pengaruh mediasi (Ghozali, 2009) 


\section{HASIL PENELITIAN DAN PEMBAHASAN}

\subsection{Pengaruh Kualitas layanan dan Kewiraniagaan terhadap Kepuasan nasabah baik secara parsial ataupun simultan}

Untuk mengetahui seberapa besar pengaruh Kualitas layanan dan Kewiraniagaan terhadap Kepuasan nasabah baik secara parsial ataupun simultan, sebagai berikut:

\begin{tabular}{|l|r|r|r|r|}
\hline \multicolumn{4}{|c|}{ Model Summary } \\
\hline Model & $\mathrm{R}$ & R Square & Adjusted R Square & Std. Error of the Estimate \\
\hline 1 & $.864 \mathrm{a}$ & .746 & .740 & 1.71074 \\
\hline a. Predictors: (Constant), Kewiraniagaan (X2), Kualitas layanan (X1)
\end{tabular}

Berdasarkan hasil diatas nilai $\mathrm{R}=0,864$ artinya Kualitas layanan dan kewiraniagaan memiliki hubungan yang kuat dengan kepuasan nasabah. Sedangkan nilai R Squre $=0,746$ artinya kualitas layanan dan kewiraniagaan berpengaruh positif terhadap kepuasan nasabah sebesar 74,6\%. Dengan demikian semakin baik Kualitas layanan kerja dan kewiraniagaan maka kepuasan nasabah cenderung akan semakin meningkat.

Berdasarkan hasil perhitungan, diperoleh $\mathrm{Sig}=0,000$ sedangkan tingkat kesalahan sebesar 5\% atau $(\alpha=0,05)$ sehingga $\mathrm{P}$ value $<\alpha$ atau $0,000<0,05$ maka Ho ditolak dan Ha diterima sehingga hipotesis diterima. Artinya secara simultan terdapat pengaruh yang signifikan dari kualitas layanan dan kewiraniagaan terhadap kepuasan nasabah, sehingga hipotesis teruji kebenarannya. Hasil penelitian ini sejalan dengan Hui, Kandampully dan Juwaheer (2009) beserta pemikiran Lai, Griffin dan Babin (2009) yang menyatakan bahwa kualitas pelayanan berpengaruh positif terhadap kepuasan pelanggan. Kualitas pelayanan yang baik memiliki arti penting bagi kelangsungan hidup perusahaan karena dapat menciptakan kepuasan pelanggan. Juga sesuai dengan penelitian Afifi (2012) bahwa Prospect and Qualifying, Preapproach, Presentasion and Demonstration, Overcoming Objections, Closing, Follow up and maintenance dapat memberikan kepuasan kepada konsumen.

Untuk mengetahui seberapa besar pengaruh Kualitas layanan dan kewiraniagaan, terhadap kepuasan nasabah secara parsial, digunakan struktur path analisys atau analisis jalur. Secara lengkap hubungan kausalitas antara variabel Kualitas layanan dan kewiraniagaan terhadap kepuasan nasabah dapat digambarkan sebagai berikut

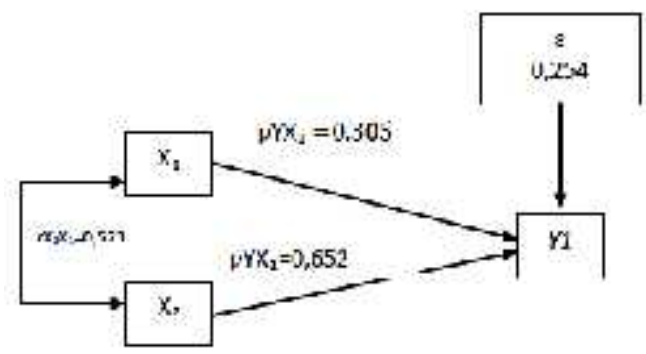


Dari diatas, dapat diketahui nilai koefisien jalur antara variabel independen dan dependen. Nilai koefisien jalur variabel kualitas layanan (X1) dengan kepuasan nasabah ( $\rho Y 1 X 1)$ sebesar 0,652. Nilai koefisien jalur variabel kewiraniagaan (X2) dengan kepuasan nasabah ( $\rho$ Y1X2) sebesar 0,305 serta epsilon sebesar 0,254. Berdasarkan nilai koefisien jalur tersebut secara rinciannya dapat diuraikan sebagai berikut:

\begin{tabular}{|l|c|}
\hline \multicolumn{1}{|c|}{ Keterangan } & Nilai \\
\hline Pengaruh $\mathrm{X}_{1}$ terhadap $\mathrm{Y}_{1}$ secara langsung $\left(\mathrm{py}_{1} \mathrm{x}_{1}\right)^{2}$ & 0,4251 \\
\hline Pengaruh $\mathrm{X}_{1}$ terhadap $\mathrm{Y}_{1}$ melalui $\mathrm{X}_{2}$ py $\mathrm{X}_{1 . \mathrm{X} 1 \mathrm{X}_{2} . \mathrm{py}_{1} \mathrm{X}_{2}}$ & 0,1139 \\
\hline Pengaruh Total $\mathbf{X}_{1}$ terhadap $\mathrm{Y}_{1}$ & $\mathbf{0 , 5 3 9 0}$ \\
\hline Pengaruh $\mathrm{X}_{2}$ terhadap $\mathrm{Y}_{1}$ secara langsung $\left(\mathrm{py}_{1} \mathrm{X}_{2}\right)^{2}$ & 0,0930 \\
\hline Pengaruh $\mathrm{X}_{2}$ terhadap $\mathrm{Y}_{1}$ melalui $\mathrm{X}_{1}$ py $\mathrm{X}_{1 . \mathrm{X} 1 \mathrm{X} 2 .} \mathrm{py}_{1} \mathrm{X}_{2}$ & 0,1139 \\
\hline Pengaruh Total $\mathbf{X}_{2}$ terhadap $\mathbf{Y}_{1}$ & $\mathbf{0 , 2 0 6 9}$ \\
\hline Pengaruh $\mathrm{X}_{1}, \mathbf{X}_{2}$ secara bersama-sama terhadap $\mathrm{Y}_{1}$ & $\mathbf{0 , 7 4 5 9}$ \\
\hline Pengaruh Variabel lain & $\mathbf{0 , 2 5 4 1}$ \\
\hline
\end{tabular}

Berdasarkan Tabel 1 diatas terlihat bahwa : Pengaruh kualitas layanan terhadap kepuasan sebesar 0,5390 atau 53,90\% dan pengaruh kewiraniagaan terhadap kepuasan sebesar 0,2069 atau $20,69 \%$.

\subsection{Pengaruh Kualitas layanan dan Kewiraniagaan terhadap Loyalitas nasabah baik secara parsial ataupun simultan}

\begin{tabular}{|l|c|c|r|r|}
\hline \multicolumn{5}{|c|}{ Model Summary } \\
\hline Model & $\mathrm{R}$ & R Square & Adjusted R Square & Std. Error of the Estimate \\
\hline 1 & $.798^{\mathrm{a}}$ & .637 & .630 & 2.53480 \\
\hline \multicolumn{4}{|l|}{ a. Predictors: (Constant), Kewiraniagaan (X2), Kualitas layanan (X1) } \\
\hline
\end{tabular}

Berdasarkan hasil diatas nilai $\mathrm{R}=0,798$ artinya kualitas layanan dan kewiraniagaan memiliki hubungan yang kuat dengan loyalitas nasabah. Sedangkan nilai $\mathrm{R}$ Square $=0,637$ artinya kualitas layanan dan kewiraniagaan berpengaruh positif terhadap loyalitas nasabah sebesar $63,7 \%$. Berdasarkan hasil perhitungan, diperoleh $\mathrm{Sig}=0,000$ sedangkan tingkat kesalahan sebesar 5\% atau $(\alpha=0,05)$ sehingga $P$ value $<\alpha$ atau $0,000<0,05$ maka Ho ditolak dan Ha diterima sehingga hipotesis diterima. Artinya secara simultan terdapat pengaruh yang signifikan dari kualitas layanan dan kewiraniagaan terhadap loyalitas nasabah.

\subsection{Pengaruh Kualitas layanan dan Kewiraniagaan terhadap Loyalitas nasabah}




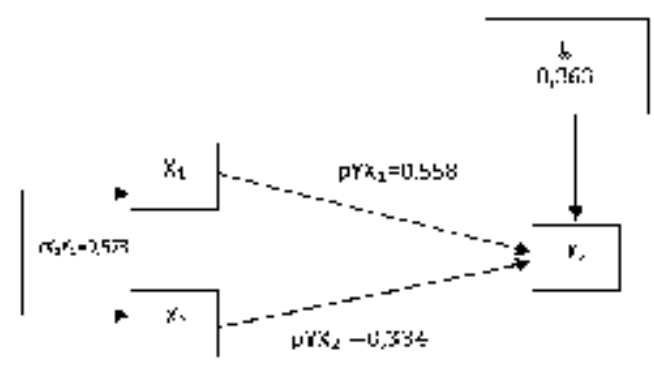

Dari Gambar di atas, dapat diketahui nilai koefisien jalur antara variabel independen dan dependen. Nilai koefisien jalur variabel kualitas layanan (X1) dengan loyalitas nasabah ( $\rho Y 2 X 1)$ sebesar 0,558. Nilai koefisien jalur variabel kewiraniagaan (X2) dengan loyalitas nasabah ( $\rho$ Y2X2) sebesar 0,334 serta epsilon sebesar 0,363. Berdasarkan nilai koefisien jalur tersebut secara rinciannya dapat diuraikan sebagai berikut:

\begin{tabular}{|c|c|}
\hline Keterangan & Nilai \\
\hline Pengaruh $\mathrm{X}_{1}$ terhadap $\mathrm{Y}_{1}$ secara langsung $\quad\left(\mathrm{py}_{1} \mathrm{x}_{1}\right)^{2}$ & 0,3113 \\
\hline Pengaruh $\mathrm{X}_{1}$ terhadap $\mathrm{Y}_{1}$ melalui $\mathrm{X}_{2} \mathrm{py}_{1} \mathrm{X}_{1 . \mathrm{X} 1 \mathrm{X} 2 .}$ py $\mathrm{x}_{2}$ & 0,1068 \\
\hline Pengaruh Total $\mathrm{X}_{1}$ terhadap $\mathrm{Y}_{1}$ & 0,4181 \\
\hline Pengaruh $\mathrm{X}_{2}$ terhadap $\mathrm{Y}_{1}$ secara langsung $\left(\mathrm{py}_{1} \mathrm{x}_{2}\right)^{2}$ & 0,1116 \\
\hline Pengaruh $\mathrm{X}_{2}$ terhadap $\mathrm{Y}_{1}$ melalui $\mathrm{X}_{1}$ py $_{1} \mathrm{x}_{1 . \mathrm{X} 1 \mathrm{X} 2}$. py $\mathrm{x}_{2}$ & 0,1068 \\
\hline Pengaruh Total $\mathrm{X}_{2}$ terhadap $\mathrm{Y}_{1}$ & $\mathbf{0 , 2 1 8 4}$ \\
\hline Pengaruh $X_{1}, X_{2}$ secara bersama-sama terhadap $Y_{1}$ & $\mathbf{0 , 6 3 6 5}$ \\
\hline Pengaruh Variabel lain & $\mathbf{0 , 3 6 3 5}$ \\
\hline
\end{tabular}

Berdasarkan tabel diatas terlihat bahwa: Pengaruh kualitas layanan terhadap loyalitas sebesar 0,4181 atau $41,81 \%$ dan pengaruh kewiraniagaan terhadap loyalitas sebesar 0,2184 atau $21,84 \%$.

\subsection{Pengaruh Kepuasan Terhadap Loyalitas Nasabah}

\begin{tabular}{|l|c|c|c|r|}
\hline \multicolumn{3}{|c|}{ Model Summary } \\
\hline Model & $\mathrm{R}$ & R Square & Adjusted R Square & Std. Error of the Estimate \\
\hline 1 & $.790^{\mathrm{a}}$ & .625 & .621 & 2.56527 \\
\hline \multicolumn{2}{|l|}{ a. Predictors: (Constant), Kepuasan } & \\
\hline
\end{tabular}

Berdasarkan Tabel di atas terlihat bahwa kepuasan nasabah mempunyai pengaruh kuat terhadap loyalitas. Hal ini ditunjukkan oleh $r$ hitung sebesar 0,790 dan koefisien determinasi sebesar $62,5 \%$. Uji hipotesis didapatkan t hitung $=12,774$ sedangkan $t$ tabel sebesar 1,66 dengan demikian $\mathrm{t}$ hitung $>\mathrm{t}$ table sehingga hipotesis yang menyatakan bahwa terdapat pengaruh positif kepuasan terhadap loyalitas kerja diterima.

\subsection{Pengaruh Kualitas layanan, Kewiraniagaan dan Kepuasan terhadap Loyalitas}

\section{Nasabah}


Pengaruh kualitas layanan (X1) dan kewiraniagaan (X2) terhadap Kepuasan Nasabah (Y1) dan dampaknya terhadap Loyalitas (Y2) nasabah.

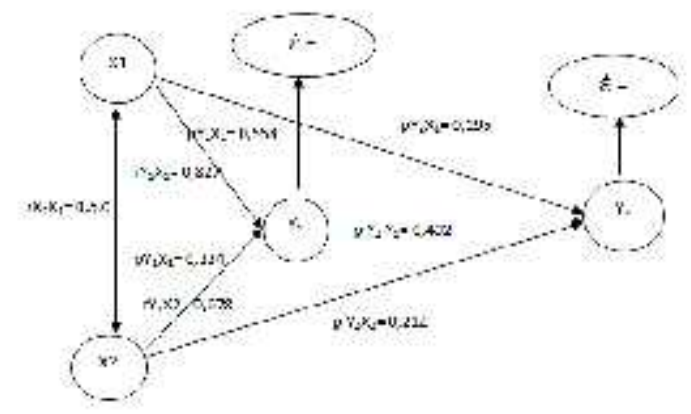

Berdasarkan Gambar di atas dapat dibuat ringkasan hasil estimasi parameter model sebagai berikut:

\begin{tabular}{|c|c|c|c|c|}
\hline Model & Koefisien Jalur & $\mathbf{t}$ & $\rho$ & $\mathbf{r}^{2}$ \\
\hline \multicolumn{5}{|c|}{ Sub Structural $1\left(\mathrm{X}_{1}, \mathrm{X}_{2}\right.$ Ke $\left.\mathrm{Y}_{1}\right)$} \\
\hline $\mathrm{X}_{1}\left(\mathrm{p} \mathrm{Y}_{1} \mathrm{X}_{1}\right)$ & 0,558 & 10.434 & 0,000 & \multirow{2}{*}{0,746} \\
\hline $\mathrm{X}_{2}\left(\mathrm{p} \mathrm{Y}_{1} \mathrm{X}_{2}\right)$ & 0,334 & 4.879 & 0,000 & \\
\hline \multicolumn{5}{|c|}{ Sub Structural $2\left(X_{1}, X_{2} \operatorname{Ke~} Y_{2}\right)$} \\
\hline $\mathrm{X}_{1}\left(\mathrm{pY}_{2} \mathrm{X}_{1}\right)$ & 0,296 & 2.880 & 0,005 & \multirow{3}{*}{0,678} \\
\hline $\mathrm{X}_{2}\left(\mathrm{pY}_{2} \mathrm{X}_{2}\right)$ & 0,212 & 2.690 & 0,008 & \\
\hline $\mathrm{Y}_{1}\left(\mathrm{p} \mathrm{Y}_{2} \mathrm{Y}_{1}\right)$ & 0,402 & 3.499 & 0,001 & \\
\hline
\end{tabular}

Adapun pengaruh masing-masing variable bebas terhadap variable terikat baik secara langsung maupun tidak langsung penulis sajikan dalam tabel berikut ini:

\begin{tabular}{|c|c|}
\hline Keterangan & \multirow{2}{*}{ Nilai } \\
\hline Pengaruh X1 terhadap $\mathrm{Y}_{1}$ & \\
\hline Pengaruh langsung $\mathrm{X}_{1}$ Terhadap $\mathrm{Y}_{1}$ & 0,3113 \\
\hline Pengaruh tidak langsung $X_{1}$ Terhadap $Y_{1}$ melalui $X_{2}$ & 0,1068 \\
\hline Pengaruh Total $\mathrm{X}_{1}$ terhadap $\mathrm{Y}_{1}$ & 0.4181 \\
\hline \multicolumn{2}{|l|}{ Pengaruh X2 terhadap $\mathrm{Y}_{1}$} \\
\hline Pengaruh langsung $\mathrm{X}_{2}$ Terhadap $\mathrm{Y}_{1}$ & 0,1116 \\
\hline Pengaruh tidak langsung $\mathrm{X}_{2}$ Terhadap $\mathrm{Y}_{1}$ melalui $\left(\mathrm{X}_{1}\right)=$ & 0,1068 \\
\hline Pengaruh total $\left(\mathrm{X}_{2}\right)$ terhadap $\mathrm{Y}_{1}$ & 0,2184 \\
\hline Total Pengaruh X1, X2 terhadap $\mathrm{Y}_{1}$ & 0.6365 \\
\hline \multicolumn{2}{|l|}{ Pengaruh X1 terhadap $\mathrm{Y}_{2}$} \\
\hline Pengaruh langsung $\mathbf{X}_{1}$ Terhadap $\mathbf{Y}_{2}$ & 0.0876 \\
\hline \multicolumn{2}{|l|}{ Pengaruh tidak langsung $\mathrm{X}_{1}$ Terhadap $\mathbf{Y}_{2}$ melalui $\mathrm{X}_{2}=$} \\
\hline & 0.0359 \\
\hline Pengaruh tidak langsung $\mathrm{X}_{1}$ Terhadap $\mathbf{Y}_{2}$ melalui $\mathrm{Y}_{1}=$ & 0.0984 \\
\hline Pengaruh Total $\mathrm{X}_{1}$ terhadap $\mathrm{Y}_{2}$ & 0.2220 \\
\hline Pengaruh X2 terhadap $\mathrm{Y}_{2}$ & \\
\hline
\end{tabular}




\begin{tabular}{|l|l|}
\hline Pengaruh langsung $\mathrm{X}_{2}$ Terhadap $\mathbf{Y}_{\mathbf{2}}$ & 0.0499 \\
\hline Pengaruh tidak langsung $\mathrm{X}_{2}$ Terhadap $\mathrm{Y}_{2}$ melalui $\left(\mathrm{X}_{1}\right)=$ & 0.0359 \\
\hline Pengaruh tidak langsung $\mathrm{X}_{2}$ Terhadap $\mathbf{Y}_{\mathbf{2}}$ melalui $\mathrm{Y}_{1}=$ & 0.0984 \\
\hline Pengaruh Total $\mathbf{X}_{\mathbf{2}}$ terhadap $\mathbf{Y}_{\mathbf{2}}$ & 0.1842 \\
\hline Total Pengaruh X1, X2 terhadap $\mathbf{Y}_{\mathbf{2}}$ & 0.4062 \\
\hline Pengaruh $\mathrm{Y}_{1}$ Terhadap $\mathbf{Y}_{\mathbf{2}}$ & 0.1616 \\
\hline Totla Pengaruh $\mathrm{X} 1, \mathbf{X} 2$, dan $\mathrm{Y}_{1}$ terhadap $\mathbf{Y}_{\mathbf{2}}$ & 0.6780 \\
\hline Pengaruh Lain & 0,3220 \\
\hline
\end{tabular}

Untuk menguji signifikansi variabel mediasi diuji dengan Sobel test sebagai berikut :

1. Pengaruh Kualitas layanan dan Kewiraniagaan terhadap Kepuasan nasabah.Berdasarkan hasil perhitungan diperoleh nilai $\mathrm{t}$ hitung sebesar 3,040 > t tabel 1,67 dengan demikian koefisien mediasi signifikan. Hal ini berarti bahwa kewiraniagaan dapat memediasi pengaruh kualitas layanan terhadap kepuasan nasabah.

2. Pengaruh Kualitas layanan dan Kewiraniagaan terhadap Loyalitas nasabah. Berdasarkan hasil perhitungan diperoleh nilai $\mathrm{t}$ hitung sebesar 3,557>t tabel 1,67 dengan demikian koefisien mediasi signifikan. Hal ini berarti bahwa kewiraniagaan dapat memediasi pengaruh kualitas layanan terhadap loyalitas nasabah.

\subsection{Pembahasan}

\subsubsection{Pengaruh Kualitas layanan dan kewiraniagaan terhadap kepuasan nasabah secara simultan}

Berdasarkan hasil penelitian menunjukkan bahwa Kualitas layanan dan kewiraniagaan memiliki hubungan yang signifikan dengan kepuasan nasabah dengan $F$ hitung sebesar 142,225 > dari F tabel. Dengan demikian semakin baik Kualitas layanan kerja dan kewiraniagaan, maka kepuasan nasabah cenderung akan semakin meningkat. Hasil penelitian ini menguatkan hasil penelitian Rima (2010) menunjukkan bahwa Kualitas layanan kerja yang menurun tidak bisa dipungkiri akan berdampak kepada kinerja organisasi yang tidak optimal. Kualitas layanan yang rendah dari karyawan dapat disebabkan oleh rasa ketidakpuasan karyawan. Rasa tidak puas ini dapat ditimbulkan dari perasaan bahwa ada kebutuhan yang belum dipenuhi oleh organisasi sehingga kontribusi pelaksanaan pekerjaan yang diberikan oleh karyawan tersebut belum optimal. Kewiraniagaan dipercaya sebagai perekat dalam organisasi yang mengalami perubahan. Membangun kewiraniagaan tentu tidak semudah mengucapkannya, harus melalui suatu proses lama dan berkelanjutan. Disebut berkelanjutan karena nilai-nilai dan norma-norma yang terkandung dalam budaya tersebut terus menerus mengalami perubahan dan berkembang sesuai dengan zamannya. Oleh karena itu 
kewiraniagaan perlu dibangun sedemikian rupa agar fleksibel, adaptif dan akomodatif terhadap aneka perubahan sehingga cita-cita organisasi yang memiliki keunggulan bukan sekedar impian sehingga dapat meningkatkan kepuasan kerja.

Berdasarkan hasil penelitian diketahui bahwa terdapat 21,5\% variabel lain selain Kualitas layanan dan budaya perusahaan yang mempengaruhi kepuasan kerja diantaranya hasil penelitian terdahulu yaitu lingkungan kerja dan kepuasan kerja, kompensasi, dan gaya kepemimpinan.

\subsubsection{Pengaruh Kualitas layanan terhadap kepuasan nasabah}

Hasil analisis data secara statistik diperoleh nilai t hitung sebesar 10,434 > t table 1,66. Hal ini membuktikan bahwa terdapat pengaruh positif dan signifikan variabel Kualitas layanan terhadap kepuasan nasabah. Konsep Kualitas layanan, merupakan sebuah konsep penting studi tentang kinerja individual. Dengan demikian Kualitas layanan berarti pemberian motif, penimbulan motif atau hal yang menimbulkan dorongan atau keadaan yang menimbulkan dorongan. Dapat juga dikatakan bahwa Kualitas layanan adalah faktor yang mendorong orang untuk bertindak dengan cara tertentu. Kualitas layanan merupakan kegiatan yang mengakibatkan, menyalurkan dan memelihara perilaku manusia. Kualitas layanan ini merupakan subjek yang penting bagi manajer, karena manajer harus bekerja dengan dan melalui orang lain. Manajer perlu memahami orang-orang yang berperilaku tertentu agar dapat mempengaruhinya untuk bekerja sesuai dengan yang diinginkan organisasi.

Kualitas layanan merupakan hal yang sangat penting untuk diperhatikan oleh pihak manajemen bila mereka menginginkan setiap karyawan dapat memberikan kontribusi positif terhadap pencapaian tujuan perusahaan, karena dengan Kualitas layanan, seorang karyawan akan memiliki semangat yang tinggi dalam melaksanakan tugas yang dibebankan kepadanya. Tanpa Kualitas layanan, seorang karyawan tidak dapat memenuhi tugasnya sesuai standar atau bahkan melampaui standar karena apa yang menjadi motif dan Kualitas layanannya dalam bekerja tidak terpenuhi. Sekalipun seorang karyawan memiliki kemampuan operasional yang baik bila tidak memiliki Kualitas layanan dalam bekerja, hasil akhir dari pekerjaannya yang tidak memuasakan.

\subsubsection{Pengaruh kewiraniagaan terhadap kepuasan nasabah}

Hasil analisis data secara statistikt hitung sebesar 4,879>t table 1,66 membuktikan bahwa terdapat pengaruh positif dan signifikan antara variabel kewiraniagaan terhadap kepuasan nasabah. Dalam penelitian ini ditemukan pengaruh positif dan signifikan antara kewiraniagaan dengan kepuasan nasabah. Ini berarti bahwa semakin baik kewiraniagaan yang 
terjadi disuatu organisasi, maka semakin baik pula kepuasan nasabah. Sebaliknya semakin kurang kewiraniagaan maka semakin kurang kepuasan nasabah.

Hasil penelitian ini mendukung hasil penelitian terdahulu atau konsisten dengan beberapa teori yang menyatakan bahwa ada beberapa penyebab yang dapat mempengaruhi kepuasan nasabah dalam sebuah organisasi. Salah saatu penyebab dari berbagai pengaruh yang ada adalah kewiraniagaan dalam organisasi. Hasil penelitian ini menunjukkan bahwa kewiraniagaan memiliki pengaruh positif dan signifikan terhadap kinerja karyawan. Setiap organisasi memiliki budaya dan pengaruh yang signifikan terhadap sikap dan prilaku anggota. Seringkali budaya dalam suatu organisasi berkembang dengan kuat, sehingga dalam kondisi demikian, setiap anggota mengetahui dengan baik tujuan organisasi yang akan dicapainya.

\subsubsection{Pengaruh kepuasan nasabah terhadap Loyalitas}

Berdasarkan hasil penelitian terlihat bahwa kepuasan nasabah mempunyai pengaruh kuat terhadap loyalitas dengan $r$ hitung sebesar 0,790 dan koefisien determinasi sebesar 62,5\% serta Uji hipotesis didapatkan $\mathrm{t}$ hitung $=12,774>\mathrm{t}$ table . hal ini menunjukkan Kepuasan pelanggan menempati posisi penting dalam praktek di dunia bisnis karena manfaat yang dapat ditimbulkannya bagi perusahaan. Pertama, banyak peneliti setuju bahwa konsumen yang terpuaskan cendrung akan menjadi loyal (Suhartanto, 2012). Konsumen yang puas terhadap barang dan jasa yang dikonsumsinya akan mempunyai kecendrungan untuk membeli ulang dari produsen yang sama. Kedua, kepuasan merupakan faktor yang akan mendorong adanya komunikasi dari mulut ke mulut yang bersifat positif (Suhartanto, 2012). Bentuk dari komunikasi dari mulut ke mulut yang disampaikan oleh orang yang puas ini bisa berbentuk rekomendasi kepada calon konsumen lain, dorongan kepada rekan untuk melakukan bisnis dengan penyedia di mana konsumen puas dan mengatakan ha-hal yang baik tentang penyedia jasa tersebut. Faktor terakhir dari efek kepuasan pelanggan terhadap perilaku adalah pelangan yang puas cendrung untuk mempertimbangkan penyedia jasa yang mampu memuaskan sebagai pertimbangan pertama jika ingin membeli barang atau jasa yang sama. Faktor terakhir ini dikenal sebagai faktor kognitif yang ditimbulkan oleh adanya kepuasan (Suhartanto, 2012).

\section{KESIMPULAN}

Berdasrkan hasil analisis yang dilakukan, dinyatakan bahwa kualitas pelayanan dan kewiraniagaan berpengaruh positif dan signifikan terhadap kepuasan nasabah baik secara parsial maupun simultan. Kualitas pelayanan dan kewiraniagaan berpengaruh positif dan signifikan terhadap loyalitas nasabah baik secara parsial maupun simultan Kepuasan dinyatakan berpengaruh positif dan signifikan terhadap loyalitas nasabah 


\section{SARAN DAN UCAPAN TERIMAKASIH}

Berdasarkan deskripsi variabel penelitian, terlihat bahwa terdapat responden merasa kurang puas terhadap kepedulian karyawan terhadap keperluan nasabah, oleh karena pimpinan perlu meningkatan emphaty dari karyawannya dalam menghadapi nasabah. Pimpinan harus berusaha untuk dapat menciptakan nasabah yang tidak hanya sekedar puas terhadap perlayanan yang diberikan, dengan harapan memperoleh nasabah yang loyal terhadap perusahaan. Manajemen perlu untuk lebih menekankan program total customer satisfaction melalui strategi yang berpusat pada kualitas layanan untuk mendapatkan nasabah yang loyal 


\section{DAFTAR PUSTAKA}

Akbar dan Parves, 2009 Impact of Service Quality, Trust, and Customer Satisfaction Loyalty, ABAC Journal, Vol. 29, No.1.Januari, 24-38

Arun Kumar. 2009. Sales management. Jakarta: PT Gramedia.

Chen dan Quester, 2006 The Influence of The Country of Origin Image, Product Knowledge and Product Involvement on Consumer Purcahse Decision: An Empirical Study of Insurance and Catering Service in Taiwan. Journal of Consumer Marketing.

Dharmesta, B.S. 1999. "Loyalitas Pelanggan:Sebuah Kajian Konseptual Sebagai Panduan Bagi Peneliti”. Jurnal Ekonomi \& Bisnis Indonesia, 14(3):73-88

Ghozali, Imam. 2009. Aplikasi Analisis Multivariate dengan Program SPSS. Edisi Ketujuh. Semarang : Badan Penerbit Universitas Diponegoro.

Hsin-Hui (Sunny) Hu, Jay Kandampully \& Thanika Juwaheer. 2009. Relationships and impacts of service quality, perceived value, customer satisfaction, and image an empirical study. The Services Industries Journal. Vol. 29, No.2, February 2009, 111-125.

Kusumadmo, 2012, Manajemen Strategik Pemasaran. Yogyakarta : Cahaya Atma Pustaka.

Ladhari, R., Ladhari, I. \& Morales, M. 2011. Bank Service Quality. The International Journal of Bank Marketing, 29(3): 224-246.

Lai. F, Griffin. M and Barry J. Babin. 2009. How Quality, Value, Image, and Satisfaction Create Loyalty at a Chinese Telecom. Journal of Business Research. Vol. 62. Issue 10. Pp. 980-986.

Liu dan Wu, 2012 Customer retention and cross-buying in the banking industry: An Integration of service attributes, satisfaction and trust. Journal of Financial Service Marketing, Vol. 12 No. 2 p. $132-145$

Lu, Y. and Y. Seock, 2008. The influence of grey consumers service quality perception on satisfaction and store loyalty behavior. Int. J. Retail Distrib. Manage., 36: 907-918

Mardalis Ahmad, 2012. Meraih Loyalitas Pelanggan. Jakarta : Balai Pustaka

Philip Kotler dan Michael Keller. 2009. Manajemen Pemasaran, Jilid 1. Jakarta : PT Macanan Jaya Cemerlang

Philip Kotler. 2012. Manajemen Pemasaran di Indonesia : Analisis, Perencanaan, Implementasi dan Pengendalian. Jakarta : Salemba Empat

Philip Kotler. 2012. Manajemen Pemasaran, Jilid 1. Jakarta : Prehalindo

Putra, 2008 Value Marketing Paradigma Baru Pemasaran. Jakarta. Selatan: PT.Salemba Empat

Semuel H, 2006 Pengaruh Satisfaction dan Trust terhadap Purchase. Intention di Starbucks The Square Surabaya. Jurnal Manajemen Pemasaran. Petra, 2(1), 1-10

Siddiqi, Kazi Omar. 2011. Interrelations Between Service Quality Attribut, Customer Satisfaction, and Customer Loyalty in The Retail Banking Sector in Bangladesh. International Journal of Business and Management. Vol.06 No.3

Sugiyono, 2009 Metode Penelitian Bisnis (Pendekatan Kuantitatif, Kualitatif, dan R\&D). Bandung: Alfabeta

Suhartanto, Dwi. 2012. Metode Riset Pemasaran. Bandung: Alfabeta

Tjiptono, Fandy, 2008, Strategi Pemasaran, Edisi 3, ANDI: Yogyakarta

Warniati, 2012 "Pengaruh Word of Mouth Terhadap Keputusan Pembelian Pada Go-Jek Di Kota Bandung”. https://openlibrary.telkomuniversity.ac.id/pustaka/107264/pengaruh-wordofmouth-terhadap-keputusan-pembelian-pada-go-jek-di-kota-bandung.html

Warta BRI, BRI, Bank 'Wong Cilik' yang Mendunia, Investor (No. 114 Tahun VI: Desember 2010Januari 2011)

Wibisono Dermawan, 2012 Manajemen Kinerja Perusahaan . Jakarta: Erlangga

Yoswara, Yongke. Widyani, Yani. 2012. Pengembngan Content Management System (CMS) eMarketing untuk UKM di Indonesia. Bandung: Jurnal Sarjana Intitut teknologi bandung Bidang Teknik Elektro dan Informatika Volume 1, number 2 